\title{
ВПЛИВ ФАКТОРУ РОСТУ ФІБРОБЛАСТІВ 19 НА СТАН ВУГЛЕВОДНОГО ОБМІНУ У ХВОРИХ НА ЦУКРОВИЙ ДІАБЕТ 2 ТИПУ З СУПУТНЬОЮ БІЛІАРНОЮ ПАТОЛОГІЕЮ
}

\author{
Аспірант Тимошенко Галина Юріївна \\ Україна, Харків, аспірант кафедри внутрішньої медицини №3 та ендокринології Харківського \\ національного медичного університету
}

DOI: https://doi.org/10.31435/rsglobal_ws/31082019/6637

\begin{abstract}
ARTICLE INFO
Received: 20 June 2019

Accepted: 21 August 2019

Published: 31 August 2019

\section{KEYWORDS}

insulin,

glucose,

chronic cholecystitis,

diabetes mellitus,

FGF-19

ABSTRACT

This article analyzes the changes of fibroblast growth factor 19 (FRF-19) in serum content and presence of the connections between this marker and carbohydrate metabolism in patients with diabetes mellitus type 2 and chronic cholecystitis, as well as in patients with isolated chronic cholecystitis. 34 patients with type 2 diabetes mellitus and concomitant chronic cholecystitis and 31 patients with isolated chronic cholecystitis were examined in the gastroenterologic and endocrinological departments of «Regional Clinical Hospital» (Kharkiv, Ukraine). Determination of FRF-19 level was carried out by enzyme immunoassay. In patients with combined course of type 2 diabetes mellitus and concomitant chronic cholecystitis, there is a significant decrease in serum FRF-19 concentration, an increase in glycemia, insulinemia and insulin resistance, determined by the HOMA index, compared with patients with isolated chronic cholecystitis, in whom high concentrations of FRF-19 were accompanied by no disturbance of carbohydrate metabolism.
\end{abstract}

Citation: Тимошенко Г. Ю. (2019) Vplyv Faktoru Rostu Fibroblastiv 19 na Stan Vuhlevodnoho Obminu u Khvorykh na Tsukrovyi Diabet 2 Typu z Suputnoiu Biliarnoiu Patolohiieiu. World Science. 8(48), Vol.2. doi: 10.31435/rsglobal_ws/31082019/6637

Copyright: (C) 2019 Тимошенко Г. Ю. This is an open-access article distributed under the terms of the Creative Commons Attribution License (CC BY). The use, distribution or reproduction in other forums is permitted, provided the original author(s) or licensor are credited and that the original publication in this journal is cited, in accordance with accepted academic practice. No use, distribution or reproduction is permitted which does not comply with these terms.

Вступ. Цукровий діабет (ЦД) $є$ однією 3 найбільш актуальних проблем охорони здоров'я, темпи росту розповсюдженості якого мають масштаб світової епідемії $[1,3,13]$. ЦД вже давно віднесли до трійки таких, що найчастіше призводять до інвалідизації населення й смерті. В 2016 році відбулась перша глобальна доповідь Всесвітньої Організації Охорони Здоров'я (ВООЗ) стосовно проблеми ЦД. В докладі ВООЗ відокремлено, що за статистичними даними в усьому світі 422 млн людей вже страждають на ЦД. Ці дані включають офіційно зареєстрованих хворих до 2014 року. Це складає 8,5\% населення і іх кількість 3 кожним роком зростає. За даними ВООЗ, хвороба збільшує смертність в 2-3 рази й суттєво скорочує тривалість життя. При цьому кількість хворих щорічно збільшується в усіх країнах на 5-7\%, а кожні 12-15 років подвоюється [3].

ЦД притаманний поліорганний, системний характер ушкоджень. На теперішній час досліджується стан органів та систем при ЦД, бо патологічні прояви в них визначають тяжкість перебігу захворювання та тривалість життя хворого $[1,2,13]$. Останні дослідження відображають, що у хворих на ЦД 2 типу в структурі коморбідної патології захворювання органів травлення займають 2 місце після серцево-судинної патології. Серед захворювань органів травлення патологія гепатобіліарної системи на першому місці [6].

ЦД асоціюється 3 широким спектром захворювань гепатобіліарної системи, які погіршують його перебіг та прогноз $[2,4]$. Серед патогенетичних механізмів ураження печінки 
та жовчного міхура суттєву роль відіграють інсулінорезистентність (IP), підвищена продукція прозапальних цитокинів, автономна нейропатія [4].

Більш ніж у третини хворих на ЏД 2 типу спостерігаються прояви діабетичної шлунковокишкової автономної нейропатії у вигляді дисфункції жовчних шляхів та зниження тонусу жовчного міхура, що вказує на іiі ранній розвиток при ЦД $[2,10,18]$. Серед захворювань біліарної системи хронічний безкам'яний холецистит (XX) займає центральне місце і становить 35,2\%. В Україні відмічається зростання холециститу, i, за подальшими прогнозами, він буде збільшуватись, що пов'язано з порушенням характеру харчування, негативними екологічними факторами, радіацією та іншими причинами. Кожного року у світі проводиться біля 25 млн холецистектомій [5].

ХХ у хворих на ЦД виникає значно частіше, ніж у популяції в цілому. Моторика жовчного міхура у хворих на ЦД значно відрізняється від такої у пацієнтів без ЦД [2, 10]. Також спостерігається ураження позапечінкових жовчних шляхів та жовчного міхура. Зниження скоротливої активності жовчного міхура, яке змінює ентерогепатичну циркуляцію жовчних кислот, здатне не лише посилювати морфологічні та функціональні порушення травного каналу і печінки у хворих на ЦД, але й приховувати небезпеку підвищеного ризику розвитку жовчнокам'яної хвороби [8, 18]. Разом з тим процесом секреція жовчних кислот, що є найбільш специфічною функцією печінки, залишається мало висвітленим питанням при цьому захворюванні.

В останні роки спостерігається прогрес в розумінні регуляції жовчних кислот. Існує складний механізм зворотньої регуляції жовчних кислот, який включає зв'язок тонкого кишківника з печінкою через фактор росту фібробластів (ФРФ-19).

Відомо, що ФРФ-19 спричиняє вплив на роботу гепатобіліарної системи як негативний регулятор синтезу жовчних кислот [15]. ФРФ-19 здатний пригнічувати експресію гена, що кодує холестерин 7а-гідроксилазу (СYP7A1), яка, в свою чергу, є лімітуючою ланкою швидкості синтезу жовчних кислот за класичним шляхом [9]. Сьогодні даний маркер привертає увагу дослідників внаслідок мультиефектів, а саме, $\epsilon$ відомості щодо участі ФРФ-19 у метаболічних процесах [16]. ФРФ-19 регулює метаболізм глюкози шляхом супресії глюконеогенезу та збільшенням катаболізму глюкози [9]. Крім того, ФРФ-19 індукує синтез глікогена печінки інсулін-незалежним шляхом [12].

Проте відомості нечисленні. Недолік інформації щодо ефектів даного маркера у клінічних дослідженнях, а також висока розповсюдженість коморбідності патології гепатобіліарної системи та ЦД 2 типу обумовлюють актуальність наукового пошуку.

Мета дослідження - оцінити зміни вмісту ФРФ-19 у сироватці крові у хворих за коморбідності ЦД 2 типу й XX та при ізольованому XX, а також проаналізувати наявність та характер зв’язків з параметрами вуглеводного обміну.

Матеріали та методи. В умовах гастроентерологічного та ендокринологічного відділень КНП ХОР «Обласна клінічна лікарня» обстежено 34 хворих з поєднаним перебігом ЦД 2 типу й XX (19 жінок, 15 чоловіків) та 31 хворий на ізольований XX (18 жінок, 13 чоловіків). Вік хворих коливався від 44 до 75 років. Контрольна група складалася 320 здорових донорів. Склад групи донорів був репрезентативним за віком та кількістю пробандів чоловічої та жіночої статі.

Діагноз «Хронічний холецистит» верифікувався на основі клініко-анамнестичних та інструментальних даних шляхом ультразвукового дослідження та дуоденального зондування 3 урахуванням критеріїв, представлених у клінічному протоколі надання медичної допомоги хворим на хронічний холецистит (наказ МО3 України №271 від 13.06.2005 р.). Діагноз ЦД згідно класифікації порушень глікемії (ВО3, 1999 р.), рекомендаціям Американської діабетичної асоціації (ADA, 2016), а також згідно уніфікованого клінічного протоколу первинної, вторинної (спеціалізованої) та третинної (високоспеціалізованої) медичної допомоги: цукровий діабет 2 типу (наказ МО3 України №1118 від 21.12.2012р.) [7, 17]. Верифікація діагнозу ЦД 2 типу грунтувалась на визначенні показників вуглеводного обміну (використання показників короткострокового та довгострокового вуглеводних балансів глікемічний профіль та глікозильований гемоглобін).

Критеріями виключення були кардіоваскулярна патологія (хронічна серцева недостатність більше 2А стадії, гостра серцева недостатність, гострий інфаркт міокарда), декомпесований перебіг ЦД (показники глікозильованого гемоглобіну не перевищували 8,5\%), супутня клінічно-значима патологія 3 боку інших органів та систем, наявність гострих 
запальних та загострення хронічних запальних захворювань, онкологічна патологія, зловживання алкоголем в анамнезі.

Визначення рівня ФРФ-19 здійснене імуноферментним методом (набір реактивів «BioVendor», Чехія). Вміст інсуліну визначали імуноферментним методом (набір реактивів «DRG», Німеччина), глюкози в сироватці крові глюкозоксидантним методом (набір реактивів «Felisit», Україна) в плазмі крові натщесерце з розрахунком індексу IP НОМА за формулою: НОМА = концентрація інсуліну (мкОД/мл) × глюкоза натщесерце (ммоль/л) / 22,5.

Статистична обробка отриманих даних проводилася 3 використанням пакету статистичних програм «Microsoft Excel». Дані представлено у вигляді середніх величин та похибки середнього. Статистична значимість різних середніх визначалася за критерієм FФішера. Аналіз взаємозв’язків проведено за допомогою кореляції R Пірсона.

Результати та їх обговорення. У хворих за коморбідності ЦД 2 типу та ХХ, які увійшли до основної групи, рівень ФРФ-19 був нижче у 1,7 раза при порівнянні 3 групою зіставлення, яку складали хворі з ізольованим XX (p<0,01). Результати наведені у таблиці 1

Таблиця 1. Показники вуглеводного обміну, ФРФ-19 у хворих за коморбідності ЦД 2 типу й XX та при ізольованому XX

\begin{tabular}{|c|c|c|c|}
\hline & 1 & 2 & 3 \\
\hline $\begin{array}{c}\text { Показник, одиниця } \\
\text { вимірювання }\end{array}$ & $\begin{array}{c}\text { Хронічний холецистит } \\
3 \text { цукровим діабетом } 2 \\
\text { типу } \\
\end{array}$ & $\begin{array}{c}\text { Ізольований хронічний } \\
\text { холецистит }\end{array}$ & Контрольна група \\
\hline ФРФ-19, пг/мл & $71,85 \pm 17,78$ & $\begin{array}{c}118,36 \pm 8,24 \\
\mathrm{p}_{1 \mathrm{ra} 2}<0,01 \\
\end{array}$ & $\begin{array}{c}163,92 \pm 6,67 \\
\mathrm{p}_{1 \mathrm{ra} 3}<0,05 \\
\end{array}$ \\
\hline Інсулін, мкОд/мл & $26,73 \pm 2,59$ & $\begin{array}{c}5,94 \pm 1,76 \\
\mathrm{p}_{1 \mathrm{ra} 2}<0,01 \\
\end{array}$ & $\begin{array}{l}6,31 \pm 1,27 \\
\mathrm{p}_{1 \mathrm{ra} 3}<0,05\end{array}$ \\
\hline Глюкоза, ммоль/л & $7,36 \pm 0,92$ & $\begin{array}{l}4,51 \pm 0,38 \\
\mathrm{p}_{1 \mathrm{ra} 2}<0,01\end{array}$ & $\begin{array}{l}4,38 \pm 0,85 \\
\mathrm{p}_{1 \mathrm{ra} 3}<0,05\end{array}$ \\
\hline Індекс НОМА & $11,52 \pm 0,94$ & $\begin{array}{c}0,67 \pm 0,044 \\
\mathrm{p}_{1 \mathrm{ra} 2}<0,01\end{array}$ & $\begin{array}{l}0,64 \pm 0,11 \\
\mathrm{p}_{1 \text { та } 3}<0,05\end{array}$ \\
\hline
\end{tabular}

Показники вуглеводного обміну у хворих, залучених у дослідження, виявили відмінності. У хворих першої групи вміст інсуліну достовірно перевищував такий у хворих другої групи у 4,4 рази ( $<$ 0,01). Дослідження концентрації глюкози виявило вірогідні відмінності у вигляді зростання даного параметра у 1,6 рази у хворих з поєднаним перебігом ЦД 2 типу та ХХ при зіставленні 3 хворими, що мали ізольований ХХ. Що стосується індекса НОМА, знайдено відмінності у вигляді збільшення рівня даного показника за коморбідності ЦД 2 типу та XX (різниці достовірні, $\mathrm{p}<0,01$ ). При зіставлені 3 контрольною групою параметри вуглеводного обміну, які вивчаються, були достовірно вище, а ФРФ-19 - нижче у хворих за коморбідності ЦД 2 типу та ХХ.

Таким чином, проведене дослідження виявило зміни параметрів вуглеводного обміну, характерні для ЦД 2 типу разом із зниженням активності ФРФ-19 у даної когорти хворих. Аналіз взаємозв'язків між параметрами, що вивчаються, визначив, що у хворих 3 поєднаним перебігом ЦД 2 типу та ХХ між рівнем ФРФ-19 та сировотковою концентрацією глюкози існує зв'язок зворотнього характеру $(\mathrm{R}=-0,57 ; \mathrm{p}<0,05)$.

Що стосується хворих 3 ізольованим $\mathrm{XX}$, також було знайдено зворотній зв'язок $(\mathrm{R}=-$ 0,71; $\mathrm{p}<0,05)$ між ФРФ-19 та глікемією. Такі результати вказують на те, що за умов високої активності ФРФ-19 відбувається зниження рівня глюкози, що обумовлено регуляторним ефектом даного маркера щодо гомеостаза глюкози. Отримані дані не суперечать результатам світової медичної літератури. Так, групою дослідників $[11,14]$ виявлено, що ФРФ-19 здатний впливати на вуглеводний метаболізм інсулін-незалежним Ras-ERK-p90SK шляхом, результатом чого було зниження глікемії та покращення чутливості тканин до інсуліну.

Привертає увагу той факт, що у хворих основної групи, представленої пацієнтами 3 поєднаним перебігом ШЛ 2 типу та XX, спостерігається гіперглікемія (результати наведені в таблиці).

Такі дані можуть пояснити дозозалежність ефектів ФРФ-19 [11]. Тобто за наявності ЦД 2 типу рівень ФРФ-19 неадекватний задля забезпечення фізіологічного функціонування вуглеводного обміну, у той час коли у хворих 3 ізольованим XX наявний компенсаторний 
механізм регуляціі гомеостазу глюкози 3 боку ФРФ-19. Отримані кореляційні зв'язки підтверджують дане припущення. Незважаючи на односпрямованість взаємин між показниками у хворих обох груп, вони різняться за силою. У той час коли у хворих на ЦД 2 типу з супутнім $\mathrm{XX}$ негативний зв'язок між ФРФ-19 та концентрацією глюкози мав середню силу $(\mathrm{R}=-0.57)$, у хворих з ізольованим $\mathrm{XX}$ він був сильним за силою $(\mathrm{R}=-0,71)$.

Висновки. Виявлено зв'язки між рівнем ФРФ-19 та показниками вуглеводного обміну. У хворих з поєднаним перебігом ЦД 2 типу та XX спостерігається достовірне зниження сироваткової концентрації ФРФ-19, зростання рівня глікемії, інсулінемії та інсулінорезистентності, визначеної за допомогою індекса НОМА, порівняно з хворими з ізольованим XX, у яких високі концентрації ФРФ-19 супроводжувались відсутністю порушень вуглеводного обміну.

Перспективами дослідження є оцінка змін рівнів ФРФ-19 у хворих на ХХ згідно тривалості ЦД 2 типу.

\section{ЛІТЕРАТУРА}

1. Аметов А.С. Сахарный диабет 2-го типа. Проблемы и решения / А.С. Аметов, М.А. Прудникова // М.: ГЭОТАР-Медиа. - 2016. - С. 131-162.

2. Вдовиченко В. І. Ураження травного каналу у хворих на цукровий діабет II типу / В. І. Вдовиченко, М. А. Бичков, А. В. Острогляд // Сімейна медицина. - 2014. - № 6. - С. 92-95.

3. ВОЗ, Первый глобальный доклад ВОЗ по проблеме сахарного диабета, 2016 г. http://www.who.int/en/

4. Журавлева Л.В., Кривоносова Е.М. Комплексное применение бенфотиамина и альфа-липоевой кислоты у больных с диабетической холецистопатией / Л.В. Журавлева, Е.М. Кривоносова // Практикуючий лікар. - 2013. - №3. - С. 116-120.

5. Звягинцева Т.Д. Хронический бескаменный холецистит: клиника, диагностика и лечени / Т.Д. Звягинцева, И.И. Шаргород // Східноєвропейський журнал внутрішньої та сімейної медицини. 2015. - № 2. - С. 13-19.

6. Климентьева Г.И., Курникова И.А., Маслова И.С., Мерзлякова О.Г. Проблема коморбидности у больных метаболическим синдромом и сахарным диабетом 2 типа. Материалы III научнопрактической конференции эндокринологов УФО «Актуальные проблемы современной эндокринологии», 13 июня 2013: 47-49.

7. Уніфікований клінічний протокол первинної та вторинної (спеціалізованої) медичної допомоги: цукровий діабет 2 типу (наказ МОЗ № 1118 від 21.12.2012р.). — 115 с

8. Фадєєнко Г. Д. Желчнокаменная болезнь: механизмы развития, подходы к терапии / Г. Д. Фадєєнко, В. М. Чернова // Сучасна гастроентерологія. - 2015. - № 5 (85). - С. 110-116

9. Appleby RN, Moghul I, Khan S, Yee M, Manousou P, Neal TD, et al. (2019) Non-alcoholic fatty liver disease is associated with dysregulated bile acid synthesis and diarrhea: A prospective observational study. PLoS ONE 14(1): e0211348. https://doi.org/10.1371/journal.pone.0211348.

10. Chhabra A., Grover S., Vill A. et al. Gallbladder disease in type-2 Diabetes mellitus patients. IJMDS. 2013. №2 (1). P. 7-15. www.ijmds.org

11. Fangfang Zhang, Lechu Yu, Xiufei Lin et al. Roles of Fibroblast Growth Factors 19 and 21 in Metabolic Regulation and Chronic Diseases Mol Endocrinol. 2015 Oct; 29(10): 1400-1413. doi: 10.1210/me.2015-1155

12. Fu L, John LM, Adams SH, et al. Fibroblast growth factor 19 increases metabolic rate and reverses dietary and leptin-deficient diabetes. Endocrinology 2012;145:2594-2603.

13. Law D. W. The worldwide diabetes epidemic / D. W. Law, D. LeRoith // Curr. Opin. Endocrinol. Diabetes Obes. - 2012. - Vol. 19, № 2. - P. 93-96.

14. Morton GJ, Matsen ME, Bracy DP, et al. FGF19 action in the brain induces insulin-independent glucose lowering. J Clin Invest. 2013;123(11):4799-4808.

15. Qichen Fang, Huating Li, Qianqian Song et al. Serum Fibroblast Growth Factor 19 Levels AreDecreased in Chinese Subjects With Impaired Fasting Glucose and Inversely Associated With Fasting Plasma Glucose Levels. Diabetes Care 36:2810-2814, 2013.

16. Roesch SL, Styer AM, Wood GC, Kosak Z, Seiler J, Benotti P, et al. Perturbations of fibroblast growth factors 19 and 21 in type 2 diabetes. PLOS ONE. 2015; 10: e0116928. https://doi.org/10.1371/journal.pone.0116928.

17. Standards of medical care in diabetes - 2016. American Diabetes Association // Diabetes Care. - 2016. — Vol. 39 (suppl. 1). - S.1 - S.109

18. Wen Wang M.M., Nianfeng Li M.D. The association of gallstone disease and diabetes mellitus. A metaanalysis. Saudi Med. J. 2014. №35 (9). P. 1005-1012. 